кордону. Вісник Національного університету оборони України : зб. наук. пр., Київ, НУОУ, 2014. С. $74-80$.

4. Матійків I. М. Тренінг емоційної компетентності: навч.-метод. посібник. Київ, 2012.112 с.

5. Формування навичок здорового способу життя у дітей і підлітків: за проектом “Діалог”: навч.-метод. посіб. / О. В. Вінда, О. П. Коструб, І. Г. Сомова, Н. О. Березна, М. М. Галябарник, С. В. Кириленко. 3-тє вид., переробл. і доп. Київ, 2003. 284 с.

\section{REFERENCES}

1. Biliavets, S. Ya. (2019). Metodychna systema formuvannia profesiinoi kompetentnosti maibutnikh ofitseriv-prykordonnykiv u protsesi navchannia viiskovospetsialnykh dystsyplin [Methodical system of formation of professional competence of future officers-border guards in the process of training of military-special disciplines]. Extended abstract of Doctor's thesis. Khmelnytskyi, 565 p. [in Ukrainian].

2. Haluziak, V. M., Smetanskyi, M. I. \& Shakhov, V. I.
Pedahohika: navch. posib. [Pedagogy: training manual]. 5-e vyd. vypr. i dop. Vinnytsia, 2012. 400 p. [in Ukrainian].

3. Didenko, O. V. \& Misheniuk, R. M. (2014). Kryterii, pokaznyky i rivni rozvynenosti profesiinoi kompetentnosti ofitseriv upravlinnia orhanamy okhorony derzhavnoho kordonu [Criteria, indicators and levels of development of professional competence of the officers of the state border guard authorities.]. Bulletin of the National Defense University of Ukraine: col. of scient. works, Kyiv, NUOU, pp.74-80.[in Ukrainian].

4. Matiikiv, I. M. (2012).Treninh emotsiinoi kompetentnosti: navch.-metod posibnyk [Training of emotional competence: teaching method. manual]. Kyiv, 112 p. [in Ukrainian].

5. Formuvannia navychok zdorovoho sposobu zhyttia u ditei i pidlitkiv: za proektom "Dialoh": navch.-metod. posib. [Formation of habits of healthy lifestyles to children and adolescents: the project "Dialogue": teaching method. manual]. O. V. Vinda, O. P. Kostrub, I. H. Somova, N. O. Berezna, M. M. Haliabarnyk, S. V. Kyrylenko. 3-tie vyd., pererobl. i dop. Kyiv, 2003. 284 p. [in Ukrainian].

Стаття надійшла до редакції 18.06.2019

УДК 373.2.014.62

DOI:

Світлана Івах, кандидат педагогічних наук, доиент кафедри загальної педагогіки та дошкільної освіти Дрогобииького державного педагогічного університету імені Івана Франка

\title{
КОМПОНЕНТИ ОРГАНІЗАЦІЙНОЇ КУЛЬТУРИ КЕРІВНИКІВ ЗАКЛАДІВ ДОШКІЛЬНОЇ ОСВІТИ
}

У статті розкрито поняття “організаційна культура керівника закладу освіти”,; визначено структуру організаційної культури керівників закладів дошкільної освіти (мотиваційно-ціннісний, знаннєво-діяльнісний, особистісно-регулятивний компоненти) та подано характеристику кожного з ї̈ компонентів; наголошено на інтегрованому характері змісту організаційної культури керівника, щзо пов'язано з їі реалізаиією в управлінській і педагогічній діяльностях, власній організаційній діяльностях та обумовлюється вимогами до організації освітнього прочесу, забезпечення адміністративно-господарської роботи, створення режиму дотримання норм і правил техніки безпеки в закладі дошкільної освіти.

Ключові слова: організаційні здібності; організаційна культура; керівник закладу дошкільної освіти; мотиваційно-иіннісний компонент; знаннєво-діяльнісний компонент; особистісно-регулятивний компонент.

Jim. 12.

Svitlana Ivakh, Ph.D.(Pedagogy), Associate Professor of the General Pedagogy and Preschool Education Department, Drohobych Ivan Franko State Pedagogical University

\section{COMPONENTS OF ORGANIZATIONAL CULTURE OF HEAD OF PRESCHOOL EDUCATION}

The article describes the concept "an organizational culture of the head of the institution of education", which is understood the personality, manifested in the ability to unite the subjects of educational activities, creating favorable conditions for the education and upbringing of children of preschool age, to influence subordinates and to lead oneself, involving them in collective decision of professional tasks, to establish business relationships in the pedagogical team on the basis of cooperation and partnership, adhering to the morality and ethics of behavior and communication, and which integrates with other personal qualities.

The structure of organizational culture of heads of institutions of preschool education, which consists of motivational-value, knowledge-activity, personal and regulatory components, is determined. The characteristics of each of the components are presented and emphasized on the integrated nature of the content of the organizational culture of the manager, which is connected with its implementation in the administrative and pedagogical activities, 
in its own organizational activities and is stipulated by the requirements for the organization of the educational process, provision of administrative and economic work, creation of a regime of observance of norms and rules of safety in the institution of preschool education.

It is emphasized that the high level of formation of organizational culture allows the head of the institution of preschool education to build relationships with all subjects of social and pedagogical activities on a partnership basis, to rationally distribute duties, to create the image of the institution of preschool education, as work with the pedagogical team is multifaceted and requires constant coordinated organizational actions.

Keywords: organizational skills; an organizational culture; a head of the institution of preschool education; an educational process; a motivational-value component; knowledge-activity component; a personal and regulatory component.

П остановка проблеми. Сучасна ситуація розвитку системи управління дошкільною освітою в Україні характеризується пошуком нових концепцій. Цей процес зумовлений змінами економічних відносин, суспільної свідомості, людських цінностей i орієнтацій, переходом від навчальнодисциплінарної до особистісно орієнтованої моделі вітчизняної системи освіти; становленням ринку освітніх послуг; упровадженням освітніх інновацій (педагогічних і організаційно-управлінських); входженням у міжнародний освітній простір.

3 огляду на означене актуальною $є$ проблема розвитку організаційної культури керівника як одного із провідних факторів модернізації системи освіти. Адже саме від його організаційної культури великою мірою залежить ефективність діяльності закладу дошкільної освіти, бо вона слугує засобом створення ефективної організації, яка об'єднує працівників етичними, моральними i культурними цінностями і спрямовує їх зусилля на досягнення спільної мети. Однак, значущість організаційної культури керівника не тільки в безпосередньому впливі на ефективність управлінської діяльності закладу вцілому, а й і на самореалізацію кожного його працівника.

Аналіз останніх досліджень і публікацій. У науковій літературі проблема організаційної культури в різних сферах, у тому числі й у сфері освіти достатньо висвітлена у працях українських і зарубіжних дослідників, які присвячено розкриттю сутності організаційної культури (Б. Гаєвський, М. Дороніна [3], К. Наумчик [3], I. Нємцева [7], Є. Шейн та ін.), її значення в діяльності організацій (С. Бацмай [1], М. Грачов, В. Лунячек [5], Г. Тимошко [9], Р. ЧерноволТкаченко [11]), особливостям організаційної культури керівників закладів освіти (В. Гладкова, М. Лукашевич, В. Нагаєв, Н. Огородникова [8], А. Федун, Ф. Хміль [10], С. Хриков, І. Шоробура), методам іï діагностики та формування (Л. Васильченко, І. Гавриленко, О. Гресь, В. Григораш, О. Зайченко [4], В. Мельник, О. Темченко, Р. Шаповал [12]).

Так, дослідник I. Нємцева, розкриваючи сутність організаційної культури в системі стратегічного управління закладами вищої освіти
України, стверджує необхідність вивчення ії як проблеми стратегічного управління людськими ресурсами в умовах змінного зовнішнього середовища. Характерною думкою автора $\epsilon$ орієнтування та оперативне реагування організаційної культури закладу вищої освіти на зміни, що відбуваються в суспільстві, освітянському просторі, житті кожної людини [7, 134].

У науковій роботі Г. Тимошко організаційна культура керівника закладу освіти розглядається як інтегративне особистісне утворення, що містить сукупність знань, умінь, навичок, цінностей, переконань, норм поведінки та синтез громадянських, особистісних, педагогічних, управлінських, організаційних, культурологічних складових, професійних якостей i компетентностей керівника, необхідних для успішної організації управління загальноосвітнім навчальним закладом $[9,29]$.

У межах вивчення проблеми розвитку організаційної культури керівника закладу дошкільної освіти, на нашу думку, доцільно звернутися до розробок Ф. Хміля, який вважає, що організаційна культура відображає ступінь організаційного упорядкування процесу менеджменту організації і $€$ важливою складовою культури організації $[10,476]$.

Відомий український вчений в галузі педагогічного менеджменту, В. Лунячек зауважує, що сучасний менеджер управління освітою має бути обізнаний $з$ організаційною культурою, бо саме така культура суттєво впливає на ставлення працівників до роботи. Як відомо, в педагогічному колективі існують формальні і неформальні правила, які не повинні вступати в протиріччя один до одного [5, 259 - 267]. Поділяємо думку вченого, сутність якої полягає в тому, що система діяльності організації має відповідати організаційній культурі.

Зауважимо, що зміни в системі освіти України на сучасному етапі вимагають нових підходів до управління закладами дошкільної освіти, потребують високої організаційної культури їх керівників, що засвідчує про актуальність досліджуваної проблеми. Ї̈̈ теоретична та практична значущість для реалізації соціальних запитів і насамперед потреб закладів вищої освіти 
щодо підготовки управлінських кадрів зумовили вибір теми пропонованої статті, метою якої $\epsilon$ визначення та характеристика структурних компонентів організаційної культури керівників закладів дошкільної освіти.

Виклад основного матеріалу. Про керівника освітнього закладу можна говорити як про організатора, який має добре розвинені організаторські здібності, піклується про педагогічний колектив, дисциплінує тих, хто навчає й виховує, і тих, хто навчається та виховується. Термін “організаторські здібності” допомагає роз'ясненню особистісного сенсу культури управління, однак не розкриває ï культурологічного змісту. В Українському педагогічному словнику С. Гончаренка термін “організаторські здібності" визначено як “сукупність психічних рис особистості, необхідних для успішного оволодіння організаторською діяльністю, iï ефективного виконання. Організаторські здібності передбачають спрямованість особистості (світоглядну, політичну, моральну, ділову), рівень іiі готовності (ділова компетентність, уміння навички, досвід)", риси характеру (комунікабельність, ініціативність, організованість, самостійність, емоційна врівноваженість)" [2, 240].

Вважаємо, що сучасний керівник закладу дошкільної освіти має володіти організаційною культурою, поняттям ширшим за організаторські здібності. Організаційна культура є поняттям близьким до професійно-педагогічної, управлінської культури та водночас і самостійним особистісним новоутворенням, яке виявляється в професійній сфері діяльності не лише через організаційний вплив на роботу всіх суб'єктів закладу дошкільної освіти, але й через усвідомлення й осмислення значущості розвитку власного “Я”, формування уміння самоуправління й саморегуляції, оволодіння навичками самоменеджменту.

Зокрема, у педагогічних дослідженнях М. Гедієвої, С. Пільової, Г. Тимошко організаційна культура керівника закладу освіти та його організаційна компетентність розглядаються як особистісне новоутворення, виявлення якого позитивно впливає на організацію освітнього процесу, працездатність, сумісність, згуртованість педагогічного колективу [7, 74].

Чільним питанням сучасних дослідників проблеми організаційної культури керівників закладів дошкільної освіти України є вивчення ефективності складових компонентів іії реалізації. Аналіз праць науковців 3 досліджуваної проблематики $[1 ; 4 ; 7 ; 9]$ дав змогу виокремити структурні компоненти організаційної культури керівників закладів дошкільної освіти, до яких відносимо:

- мотиваційно-ціннісний компонент, стимулювання якого орієнтує керівника на позитивні зміни в мотиваційно-ціннісній сфері особистості, виявлення поваги до працівників закладу дошкільної освіти та батьків, відчуття професійного натхнення в роботі з дошкільнятами;

- знаннєво-діяльнісний, розвиток якого сприяє обізнаності керівників закладів дошкільної освіти 3 питань організаційної діяльності, підвищує загальний рівень культури поведінки, ділового етикету;

- особистісно-регулятивний, розкриття якого мобілізує й регулює потенційні сили керівника закладу дошкільної освіти (емоційну стійкість, емпатію, комунікативність, креативність, організованість) у процесі виконання функціональних обов'язків.

Розглянемо більш детально кожен 3 виокремлених нами компонентів.

Так, мотиваційно-ціннісна спрямованість організаційної культури керівників закладів дошкільної освіти - це прагнення й бажання працювати в такому педагогічному колективі, де провідними орієнтирами є гуманізм, самоуправління, співпраця й задоволеність результатами виховання й навчання дітей дошкільного віку, підготовки їх до школи.

На думку Р. Шаповала, наявність професійно значущих ціннісних орієнтацій особистості забезпечує сумлінне ставлення до справи, пробуджує до дій, творчості й деякою мірою компенсує недостатньо розвинені вміння та навички, відсутність позитивної орієнтації може стати причиною професійного краху, втрати вже наявної педагогічної майстерності. У педагогічному колективі мають домінувати загальнолюдські цінності, серед яких терпляче і шанобливе ставлення до іншої людини, розуміння iiі потреб, адаптованість до традицій колективу, уміння працювати в колективі $[12,157]$.

У межах дослідження доцільно звернути увагу на чинники, які впливають на поведінку людини: ієрархія потреб А. Маслоу, належність, влада, успіх (теорія Макклеланда), розвиток, успіх (двофакторна модель Герцберга), очікування позитивного результату, отримання очікуваної нагороди (теорія очікувань Врума), справедливе оцінювання сил, які були витрачені, співвіднесення ïx з винагородою (теорія справедливості); успіх долає мотивацію запобігання невдачі (мотивація успіху та запобігання невдачі); вагомість, відносна цінність ділових і соціальних інтересів (теорія 


\section{КОМПОНЕНТИ ОРГАНІЗАЦЙНОЇ КУЛЬТУРИ КЕРІВНИКІВ ЗАКЛАДІВ ДОШКІЛЬНОЇ ОСВІТИ}

лідерства Блейка і Мутона); поведінка залежить від соціального статусу й ролі в групі (соціальний статус і роль у групі). Зазначені чинники впливають на мотиваційно-ціннісну сферу керівників закладів дошкільної освіти, визначають стратегію роботи $з$ працівниками закладу, батьками, дітьми, а також перспективи вдосконалення педагогічного потенціалу.

Щодо наступного компоненту організаційної культури керівників - знаннєво-діяльнісного, то у науковій літературі $[1 ; 3 ; 4 ; 7 ; 8]$ описуються характерні риси керівника освітнього закладу, серед яких переважають управлінські вміння (визначення перспективних довгострокових цілей управлінського процесу, формування стратегії, аналітичний розгляд можливостей запровадження освітніх інновацій з урахуванням внутрішніх та зовнішніх аспектів функціонування закладу в інформаційному та ринковому просторі, планування діяльності відповідно до обраної стратегії, прийняття та здійснення управлінських рішень, що адаптують навчально-виховний процес до можливих соціально зумовлених змін), гуманні якості (уміння розуміти потреби іншої людини, працювати в команді, упереджувати конфліктів педагогічному колективі, сприяти самовдосконаленню членів педагогічного колективу). Проте сучасні освітні підходи до організації співпраці, прийняття спільних управлінських рішень вимагають від керівника освітнім закладом розвинених організаторських здібностей.

Уміння розвитку організаційної культури керівника закладу дошкільної освіти схарактеризуємо як самоуправління та самоорганізацію (мобілізувати власні сили для розв'язання педагогічних завдань, з'ясовувати причиново-наслідкові зв'язки своїх успіхів і невдач, долати бар'єри самореалізації, залучати працівників і батьків до співпраці як однієї 3 важливих форм самоуправління); комунікаційні та організаційні (організовувати спілкування 3 педагогічним колективом на засадах сприйняття й розуміння потреб кожної людини, запобігати появі конфліктних ситуацій, розв'язувати педагогічні ситуації, контролювати забезпечення життєдіяльності дитячого та педагогічного колективів), діагностичні та коригувальні (виявляти причини недостатнього рівня кваліфікації педагогічних кадрів, аналізувати результативність підвищення кваліфікації педагогічних працівників та проводити їх атестацію, оперативно усувати недоліки навчальної й виховної роботи в закладі дошкільної освіти, пропонувати більш раціональні шляхи розв'язання завдань); управлінські та прогностичні (керувати педагогічним колективом на засадах співпраці та взаєморозуміння визначати стратегічні і тактичні цілі, головні завдання розвитку закладу дошкільної освіти, враховуючи специфіку педагогічної роботи, планувати позитивні зміни) [3, 59].

Щодо особистісно-регулятивного компоненту організаційної культури керівників закладів дошкільної освіти, то у науковій літературі [8; 11; 12] до професійних якостей керівника закладу освіти відносять такі, як інтелектуально-логічні: здатність формулювати проблему; аналізувати й порівнювати; виокремлювати головне та другорядне; доводити, обгрунтовувати; систематизувати, класифікувати; давати визначення; інтелектуально-евристичні: генерувати ідеї; висувати гіпотези; критичність мислення, здатність до оцінних суджень; здатність бачити проблему та суперечності; здатність долати інерцію мислення; здатність переносити знання в інші ситуації; незалежність суджень; здатність до використання аналогій; здатність відмовитися від настирливої ідеї; комунікативно-творчі: акумулювання й використання досвіду творчої діяльності інших; здатність до співробітництва та взаєморозуміння; уміння організовувати творчу діяльність інших; здатність відстоювати свою очку зору й переконувати інших у процесі творчої дискусії; здатність уникати конфліктів у процесі творчої діяльності або успішно їх розв'язувати $[8,82]$.

Педагогічні здібності (комунікативність, перцептивні здібності, динамізм особистості, емоційна стабільність, оптимістичне прогнозування, креативність) забезпечують швидкість самовдосконалення керівника закладу дошкільної освіти, позитивно впливають на створення морально-етичних відносин у педагогічному колективі. Як зазначає Р. Черновол-Ткаченко, “етика ділових відносин у педагогічному колективі ЗНН - це створення моральних підвалин, етичного спілкування, прийняття рішень, вираженого формуванням високих моральних цінностей, механізмів моральної саморегуляції, захищеності та зацікавленості, моральної творчості й комфорту, а також сприйняття морального досвіду колективу" [11, 214].

Комунікативність допомагає керівнику закладу дошкільної освіти побудувати співпрацю на засадах демократичного спілкування й розуміння потреб кожної людини, легко вступати в контакт 3 батьками дошкільнят, переконуючи їх у реалізації спільних потреб у вихованні й самовихованні, викликати позитивні емоції у співробітників, які безпосередньо працюють 3 
дітьми, отримувати задоволення від продуктивної праці.

Розвиток перцептивних здібностей, тобто професійної проникливості, пильності, педагогічної інтуїції, здатності сприймати й розуміти іншу людину, сприяють тому, що керівник закладу дошкільної освіти своєчасно помічає та усуває перешкоди, що заважають побудові моральноетичних відносин у педагогічному колективі. У діяльності керівника закладу дошкільної освіти важливими є стосунки з підлеглими, які умовно поділяються на таких, що активно виконують визначені завдання, досягають успіху; таких, що пасивно ставляться до роботи; таких, що поводять себе резистентно, тобто чинять опір дії, часто й безпідставно сперечаються з керівником, критикують організацію, не беруть участь в іiі справах $[12,156]$.

Зазначимо, що у сучасних конфліктогенних умовах важливою особистісною якістю $є$ емоційна стабільність керівника як здатність володіти собою, зберігати самоконтроль, здійснювати саморегуляцію за будь-якої ситуації. У побудові морально-етичних відносин емоційна стабільність особистості керівника $\epsilon$ регулювальною ланкою. У такому середовищі кожен учасник педагогічного колективу має змогу розвиватися, реалізувати власний потенціал, виносити позитивне для себе й оточуючих.

На наш погляд, основу професіоналізму в управлінській діяльності становлять організаторські здібності. Організаторські здібності як уміння згуртовувати педагогічний колектив на досягнення загальної мети - розвиток кожної особистості, створення умов для повноцінної самореалізації - слугують невід'ємною складовою професійної компетентності керівника закладу дошкільної освіти. Уміння організовувати роботу педагогічного колективу базується на вміннях керівника освітнього закладу стимулювати розвиток кожної особистості, iï щоденну життєдіяльність, сприяти самовихованню й саморозвитку педагогічного колективу, контролювати й допомагати працівникам в організації освітнього процесу, наповнювати зміст роботи цікавими творчими справами, розкривати творчий потенціал кожної особистості.

Висновки. Отже, організаційну культуру керівника закладу дошкільної освіти слід розглядати як особистісне новоутворення, що виникає в результаті поєднання педагогічної, управлінської, особистісної діяльності, і спричиняє позитивні свідомі зміни в особистіснопрофесійному становленні. Організаційну культуру керівника закладу дошкільної освіти утворюють мотиваційно-ціннісний, знаннєво-діяльнісний, особистісно-регулятивний компоненти. Акцентовано, що високий рівень сформованості організаційної культури дозволяє керівникові закладу дошкільної освіти будувати відносини 3 усіма суб'єктами соціально-педагогічної діяльності на партнерських засадах, раціонально розподіляти обов'язки, створювати імідж закладу дошкільної освіти, оскільки робота 3 педагогічним колективом $\epsilon$ багатогранною і вимагає постійних злагоджених організаційних дій.

Проведене дослідження не вичерпує всіх аспектів розглядуваної проблеми. Перспективними напрямами подальших досліджень вважаємо аналіз основних закономірностей та принципів, які лежать в основі розвитку організаційної культури керівника закладу дошкільної освіти.

\section{ЛІТЕРАТУРА}

1. Бацмай С. Розвиток організаційної культури керівників навчальних закладів : гендерний підхід. URL: http://mp2.umo.edu.ua/wp-content/uploads/ 2012/04/Бацмай.pdf.

2. Гончаренко С. Український педагогічний словник /гол. ред. С. Головко. Київ, 1997. 373 с.

3. Дороніна М., Наумчик К. Організаційна культура : конспект лекцій для студентів усіх спеціальностей всіх форм навчання. Харків, 2006. $80 \mathrm{c}$.

4. Зайченко О. Управління дошкільним навчальним закладом у сучасних умовах. URL: / /http://www.stattionline.org.ua/pedagog/106/19449upravlinnya- doshkilnim-navchalnim-zakladom-usuchasnix-umova41.

5. Лунячек В. Педагогічний менеджмент : підручник. Харків, 2014. 340 с.

6. Махиня Т. Розвиток управлінських умінь. Форми і методи самоосвіти керівників ДНЗ. Управління. Всеукраїнська газета для керівників із дошкільної освіти різних рівнів. № 4 (38), квітень 2014. С. 18-22.

7. Нємцева І. Організаційна культура в системі стратегічного управління вищими навчальними закладами України : монографія. Чернівці, 2012. $255 \mathrm{c}$.

8. Огородникова Н. Саморозвиток керівника як метод рефлексивного управління навчальним закладом. Управління школою. № 19 (283). Липень 2010. С. 81-84.

9. Тимошко Г. Система розвитку організаційної культури керівника загальноосвітнього навчального закладу : автореф. дис. на здобуття д-ра пед. наук : спец. 13.00.06 "Теорія і методика управління освітою”. Київ, 2015. 39 с. 
10. Хміль Ф. Основи менеджменту : підручник. Київ, 2003. 608 с.

11. Черновол-Ткаченко Р. Роль комунікаційних процесів у забезпеченні ефективного управління навчальним закладом. Наукові записки кафедри педагогіки. 2010. Вип. 24. С. 212-220.

12. Шаповал Р. Критерії та показники сформованості управлінської компетентності керівника дошкільного навчального закладу. Засоби навчальної та науково-дослідної роботи: зб. наук. пр. Харків, 2008. Вип. 29. С. 155-160.

\section{REFERENCES}

1. Baczmaj, S. Rozvytok organizacijnoyi kultury kerivnykiv navchalnykh zakladiv : gendernyj pidhid [Development of Organizational Culture of Educational Institutions: A Gender Approach]. Available at: // http://mp2.umo.edu.ua/wp-content/ uploads/2012/04/ Baczmaj.pdf. [in Ukrainian].

2. Goncharenko, S. (1997). Ukrayinskyi pedagogichnyi slovnyk [Ukrainian Pedagogical Dictionary]. (Ed.). S. Golovko. Kyiv. p. 373. [in Ukrainian].

3. Doronina, M. \& Naumchyk, K. (2006). Organizacijna kultura : konspekt lekcij dlya studentiv usix specialnostej vsix form navchannya [Organizational culture: a summary of lectures for students of all specialties of all forms of study]. Kharkiv. p. 180. [in Ukrainian].

4. Zajchenko, O. Upravlinnya doshkilnym navchalnym zakladom u suchasnyh umovax [Management of pre-school educational institutions in modern conditions].URL. http:// www.stattionline.org.ua/pedagog/106/19449upravlinnya- doshkilnim-navchalnim-zakladom-usuchasnix-umova41.[in Ukrainian].

5. Lunyachek, V. (2014). Pedagogichnyj menedzhment : pidruchnyk [Pedagogical Management]. Kharkiv, 340 p. [in Ukrainian].
6. Mahynya, T. (2014). Rozvytok upravlinskyh umin. Formy i metody samoosvity kerivnykiv DNZ [Development of managerial skills]. Forms and methods of self-education of heads of the DNR. Management. All-Ukrainian newspaper for leaders of preschool education of different levels. No. 4 (38), pp. 18-22. [in Ukrainian].

7. Nyemceva, I. (2012). Organizacijna kultura $v$ systemi strategichnogo upravlinnya vyshhymy navchalnymy zakladamy Ukrayiny [Organizational culture in the system of strategic management of higher educational institutions of Ukraine]. Chernivtsi, 255 p. [in Ukrainian].

8. Ogorodnykova N. (2010). Samorozvytok kerivnyka yakmetod refleksyvnogo upravlinnya navchalnymzakladom [Self-development of the head as a method of reflexive management of the school]. School management. No. 19 (283). Julypp. 81-84. [in Ukrainian].

9. Tymoshko, G. (2015). Systema rozvytku organizacijnoyi kultury kerivnyka zagalnoosvitn'ogo navchalnogo zakladu [System of development of organizational culture of the head of a comprehensive educational institution]. Extended abstract of Doctor's thesis. Kyiv, 39 p. [in Ukrainian].

10. Khmil, F. (2003). Osnovy menedzhmentu : pidruchnyk [Fundamentals of Management]. Textbook. Kyiv, 608 p. [in Ukrainian].

11. Chernovol-Tkachenko, R. (2010). [The role of communication processes in ensuring effective management of an educational institution]. Scientific Notes of the Department of Pedagogy. Vol. 24. pp. 212-220. [in Ukrainian].

12. Shapoval, R. (2008). Kryteriyi ta pokaznyky sformovanosti upravlinskoyi kompetentnosti kerivnyka doshkilnogo navchalnogo zakladu [Criteria and indicators of the formation of managerial competence of the head of a preschool educational institution]. Methods of educational and research work. Kharkiv. Vol. 29. pp. 155-160. [in Ukrainian].

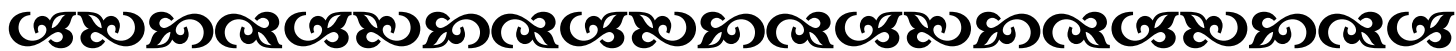

“Яиш праия світ таким, яКє, створила. Аиш в прахі варто і для прахі жить”. Іван Франко видатний український письменник, поет, публіиист, перекладач, науковеиь

"ТТри шляхи ведуть до знання: шляхроздуму - це шляхнайблагородніший, шлях наслідування - це шлях найлегший і шлях досвіду - це шлях найгірқіший”.

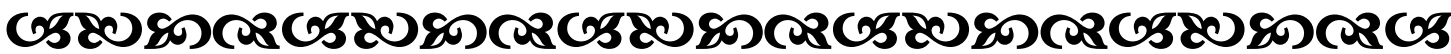

